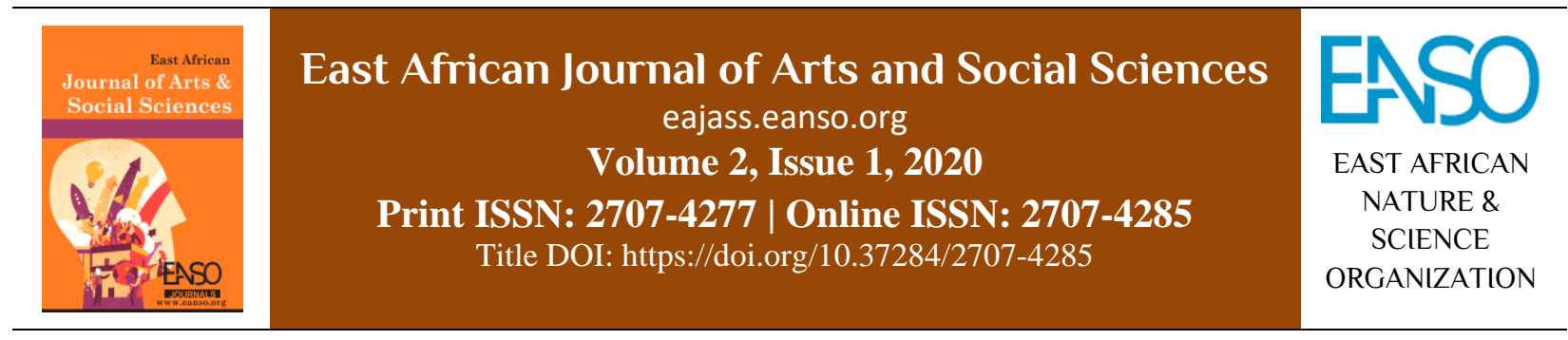

Original Article

\title{
Factors Leading to High Turnover of House Helps: A Case Study of Shaabab Estate in Nakuru Town
}

\author{
Nancy Cheseto, $P h D^{1 *}$ \\ ${ }^{1}$ Mount Kenya University, P. O. Box 342 - 01000, Thika, Kenya. \\ *Correspondence email: ncheseto@mku.ac.ke. \\ ORCID: https://orcid.org/0000-0002-7013-320X
}

Article DOI: https://doi.org/10.37284/eajass.2.1.198

Article history: ABSTRACT

27 August 2020 Most of us are familiar with the workers known as house helps. You have known them since childhood and saw them almost as much as your parents, if not more.

Keywords: They probably felt like family, even more so that some of your relatives. However, despite the presence of these pseudo-familial bonds, those working in

Workers, this profession are experiencing high turnover. Why is that? Some may argue

Turnover,

House Helps,

Shaabab Estate, Nakuru Town. the employers' plays a part and some believe it's a lack of job security. In order to ascertain a concrete understanding, all factors must be tackled individually using appropriate methodology and research approaches so as to identify hidden links that will aid in constructing the final results. What is its impact? A high turnover brings with it a whole host of effects, both positive and negative. Therefore, it is imperative to find measures to deal with such effects in a manner that enables constructive development for both the house help and the employer. How can it be addressed? Tackling this particular issue is not easy, however, upon identifying the factors driving the high turnover, proactive approaches must be taken so as to avoid or at least limit turnover of this magnitude among house helps. This paper seeks to tackle all the aforementioned issues, using reliable and verified sources, accurate figures, effective methodology and wellbuilt design.

\section{APA CITATION}

Cheseto, N. (2020). Factors Leading to High Turnover of House Helps: A Case Study of Shaabab Estate in Nakuru Town. East African Journal of Arts and Social Sciences, 2(1), 21-32. https://doi.org/10.37284/eajass.2.1.198 


\section{CHICAGO CITATION}

Cheseto, Nancy. 2020. "Factors Leading to High Turnover of House Helps: A Case Study of Shaabab Estate in Nakuru Town". East African Journal of Arts and Social Sciences 2 (1), 60-66. https://doi.org/10.37284/eajass.2.1.198.

\section{HARVARD CITATION}

Cheseto, N. (2020) "Factors Leading to High Turnover of House Helps: A Case Study of Shaabab Estate in Nakuru Town", East African Journal of Arts and Social Sciences, 2(1), pp. 60-66. doi: 10.37284/eajass.2.1.198.

\section{IEEE CITATION}

N. Cheseto, "Factors Leading to High Turnover of House Helps: A Case Study of Shaabab Estate in Nakuru Town", EAJASS, vol. 2, no. 1, pp. 60-66, Aug. 2020.

\section{MLA CITATION}

Cheseto, Nancy. "Factors Leading to High Turnover of House Helps: A Case Study of Shaabab Estate in Nakuru Town". East African Journal of Arts and Social Sciences, Vol. 2, no. 1, August 2020, pp. 60-66, doi:10.37284/eajass.2.1.198.

\section{INTRODUCTION}

At one time or another, you have come across a house help who plays a major role as a second parent but on the same, you might have also encountered numerous house helps who have shaped your behaviour up to today. At least $3 / 5$ homes have a house help meaning they comprise one of the largest numbers of employees. In contrast, it is also one of the jobs experiencing high turnover. According to Armstrong (2001), labour turnover refers to people leaving their place of work at any time for any reason. Labour turnover may have both negative and positive effects (Mobley et al., 1979). Negative effects of labour turnover include recruitment cost, induction cost, training cost, time spent looking for a replacement, training and inducting, low productivity, bad organisation image, demonisation, living cost of the house helps and also time spent during recruitment, increase the workload to the employer.

House help turnover may have a negative impact on the employer performance at the place of work and also disrupt the daily running of the house. Negative effects include recruitment cost, induction cost, time spent looking for a replacement, increased workload to the employer, among others. Labour turnover is not a unique problem for many homes. Many homes face the problem of the house helps turnover. From personal observation as a residence of Nakuru, house help turnover has been a great challenge for many households with definite comprehension of the factors contributing to the turnover. Many households depend on the house helps to run house errands; hence turnover of a house help often have insurmountable implications on the households. Therefore, it was imperative to determine the factors causing labour turnover of the house helps specifically in Shaaabab estate in Nakuru town. Objectives of the study were to find out whether terms and conditions of work of house helps lead to the high turnover of the house helps; to establish whether discrimination by the employers leading to the high turnover of the house helps, and to examine whether lack of job security leads to the high turnover of the house helps and to examine whether working conditions lead to the high turnover of the house helps. The findings of the study were envisaged to serve as a useful indicator on the factors that lead to house help turnover and the effects of house help turnover to the house help owners and to the house help so that these factors can be addressed by the house help employers. The findings can also help the government to enact laws which will address some of the issues facing house helps and protect the house helps.

\section{LITERATURE REVIEW}

According to industrial relations services and employee development bulletin, high rate of labour turnover can destabilise the performance of house helps and demotivate them. Clifton (2000) commented that labour turnover might be a function of negative job attitudes, law satisfaction, poor working conditions, favouritism, lack of motivation and other personal factors. On the other end, Cole (2004) revealed that the main factor that influenced house help to leave their place of work were career change which influenced most house helps, dissatisfaction with pay followed by 
dissatisfaction with benefits and lack of opportunities for career development. Nyaura and Ngugi (2019) found that the main factors that influence house help turnover needs for career and education advancement and dissatisfaction with supervision style at work. Muasya (2014) study found out that the major causes of the house helps to leave the houses was low salary compared to similar houses, lack of job security and poor working conditions would cause them to leave.

Labour turnover is an outcome of resignation due to dissatisfaction with working conditions, wages, poor health and sickness, old age and family circumstances. Better pay motivates house helps, supervision at work, the relationship between bosses and house helps while poor personal policies lead to house help turnover. Frequent retrenchment and redundancy may cause house helps to leave work. Armstrong (2001) cited negative job attitude, low job satisfaction, combined with the ability to secure employment elsewhere as reasons for turnover. Boxall, Macky and Rasmussen (2003) explained that the house helps turnover affected levels of productivity of the employers. According to Chipton (2000), employees can be dissatisfied if their employers do not maintain a record for each employee containing full and accurate details of payment. Gupta (2005) argues that the causes of employee turnover can be unavoidable and are initiated by either house helps or the employer in this context. The house helps avoidable causes include incompetence, laziness, insubordination, and desire to work near home. According to Gomez (1994), there are two types of labour turnover, voluntary and involuntary turnover. Voluntary turnover occurs when the house help decides to leave work for personal while involuntary turnover occurs when an employer decides to terminate the house helps due to economic necessity or a poor fit.

Pay and Benefits influence house helps mostly to leave the place of work. Gichigi (2007) recommended that management should consider pay and benefits for the employees are competitive compared to what other organisations offer. Compensation packages have great bearing on employees' attitude in an organisation. The package generally includes earnings, economic advantage and frequency of pay increments and fairness of the compensation. This will assist the house helps develop positive attitudes towards their work and also maintain a good relationship with the employers. The employer should be able to provide house helps with a comfortable environment, increase pay and some leave of absence allowance. Remuneration package cannot be underestimated as it is used to meet physiological needs.

House help retention involves providing an atmosphere in which the house helps will continue to stay longer with the employer. Retention methods include the ability of house help to speak his or her mind freely with the employer, solicit ideas and provide an environment in which house helps are comfortable in providing feedback, foreshadow the information with the house helps (Boxall, 2003). Poor supervision between the employer and the house help promotes high turnover. Nyaura and Ngugi (2019) posit that the supervision style at work between the employees and the employer should be improved. With good supervision, it ensures that the organisation runs its operations smoothly without any problem. Poor working conditions lead to house helps to leave their places of work. According to Mullins (2002), Herzberg's two-factor theory that is motivation or satisfiers and hygiene or maintenance factors argued that motivation of employees has a significant effect on their performance. House help motivation is a variable management tool for improving the house help work performance and training the house helps make them feel part of the home and improve productivity.

The organisation should develop a clear policy for career and education advancement. According to Cole (2004), the concept of employee development can be better understood if it is viewed in the context of each individual employee. Through training, an employee is enabled to achieve proficiency in his or her work. Provision of adequate and right kind of training facilities is therefore essential. Training should be related to the needs of the organisation and the concerned employees. For the ordinary workers whose job do not call for any particular administrative or supervisory skills, orientation training, induction, training in safety devices and special service training is recommended. Off the job training takes place away from the normal situation usually employing specifically simplified tools and 
equipment and the worker is regarded as not productive form the beginning (Cole, 2004). Training improves individual performance in terms of output, speed and overall productivity. Training improves the operational flexibility, thus extending the range of skills possessed by employees and this helps the employees to perform different duties and increase commitment to work. (Armstrong, 2004).

Every person needs to work in a healthy environment. Unhealthy working condition is a source of stress to both the employer and the house helps. House helps supposed to be protected against any hazards and accidents arising in the house. Every household has safety and health policies where managers should ensure that the house help is protected against any risks. Conflicts may positively or negatively affect the relationship of the employer and the house help in different ways. Conflicts may arise due to tough issues which are not known to the employer to identify the most vital issues as to curb those problems. It is good for employers to avoid conflicts that arise. Interpersonal conflicts affect a person's emotion this is because there is a need to protect self-esteem and self-image (Armstrong, 2004)

Cole (2004) stated that the main disadvantage of labour turnover is the additional cost of placement and recruitment, disruptions and additional training cost. Other disadvantages are wasted investment in people if they were trained by the organisation, difficult in attraction new and retaining old house helps, low motivation among house helps to lead to low productivity and poor corporate image. Involuntary turnover results in a very painful decision that can have a profound impact on the entire organisation, especially to the house help who loses his or her job. Heavy workload, redeployment and stress are the effects of labour turnover affecting house helps.

\section{RESEARCH METHODOLOGY}

A case study design was adopted owing to its ability to provide information on population perception, attitude, option, views and behaviour about a given subject under study. The target population for the study was 600 house helps in Shaabab estate. The sample size of the study was selected using systematic sampling whereby after every 10th house where one house help was selected hence a sample of 60 respondents representing $10 \%$ of the population and 40 employers were selected from every 17 th house forming $17 \%$ of the employers.

Table 1: Sample Size of House Helps and Employers

\begin{tabular}{lll}
\hline $\begin{array}{l}\text { House helps } \\
\text { Category }\end{array}$ & $\begin{array}{l}\text { Number of } \\
\text { houses }\end{array}$ & Sample size \\
\hline $\begin{array}{l}\text { House girls } \\
\text { Houseboys }\end{array}$ & 440 & 44 \\
Total & 160 & 16 \\
Employers & 600 & 60 \\
Male & 210 & 14 \\
Female & 390 & 26 \\
Total & 600 & 40 \\
\hline
\end{tabular}

The data was collected using open-ended and closed-ended questionnaires which were administered to the house helps and the employers. The questionnaires were hand-delivered and the researcher assisted the respondent to answer the questions for any clarification and to ensure immediate feedback. Data were analysed by use of descriptive statistics and the data was presented in the form of tables.

\section{RESULTS AND DISCUSSIONS}

Out of the 60 house help respondents, $73 \%$ (44) were female and $27 \%$ (16) female. Out of the 60 respondents who participated in the study, no house helps who were aged between 10-15 years, those aged 16-20 years were 20\%, 21-25 years were $10 \%$ and above 31 years were $10 \%$. The results revealed that $30 \%$ of the respondents had attained the primary level of education, $17 \%$ had attained secondary level, $6 \%$ had college level and the majority $47 \%$ were illiterate. This implies that the society should be sensitised to support house helps to go to school. In regard to the length of service; the majority of the house helps $(60 \%)$ had worked for their employers less than one year, 33\% worked for 1-3 years while $7 \%$ for 4 years and above. The study revealed that $30 \%$ of the house help earned a salary bracket Ksh. 1,500-2000, 37\% earn between Ksh. 2001- 3000, 20\% earn Ksh. 30001- 4000 and $13 \%$ earn a salary above Ksh 4000 . 
Out of the 44 employers that took part in the study, $65 \%$ were female while $35 \%$ were male. $10 \%$ of the employers were aged between 16-20 years, 20\% were aged $21-25$ years, $30 \%$ were aged $26-30$ years, and $40 \%$ were above 31 years. The study revealed that $60 \%$ of the employers stayed with their house helps for less than a year, and 30\% of the employers stayed with the house helps for 1-2 years. $10 \%$ of the employers stayed with their house helps between 2-3 years, and none of the employers stayed with the house helps for more than 3 years. $45 \%$ of the employers revealed that the family size caused the house help to leave work because large family size made the house helps to overwork while $55 \%$ of the employers with small family size revealed that the house helps were comfortable. The study revealed that none of the employers lived in a single room house, $20 \%$ of the employers lived in 3 bedroomed house while $40 \%$ lived in 2 bedroomed house and $40 \%$ lived in 1 bedroomed house. This shows that the majority of the house helps lived in congested houses making the leave work. The study revealed that all employers were affected by the services offered by the house helps.

Most of the respondents, 53\% revealed that there were not rewarded by their employers apart from receiving their salaries. At the same time, $47 \%$ were rewarded by the employer. Majority of the respondents $(63 \%)$ revealed that family size affects their performance, while $37 \%$ were comfortable with the family size. $53 \%$ of the respondents complained of mistreatment by the family members, overworking, and delay in salary payment, waking up very early and sleeping very late, sexual harassment, living in a small house, specific mode of dressing, following the religion of the employer, isolated eating area, eating different food from the family members, no medical care, and no social media. While $47 \%$ of respondents were comfortable where they were. The study also revealed that $98 \%$ of the house helps were not inducted on the job leading to a lot of conflict with the employer especially on the cooking methods, menu selection and on the use of electrical gadgets. 99\% of the house helps were not allowed to hold parties at the employers' premises neither to allow visitors in the houses and this made them feel socially discriminated while $10 \%$ were comfortable.
The study revealed that $50 \%$ of the house helps were unsatisfied with their salary while $33 \%$ were satisfied and $17 \%$ were very unsatisfied. The study also revealed that all the house helps were not issued with contract letters; therefore, not sure of their job security neither sure of the amount of salaries.

The house helps sampled were not given any contract letter of employment and therefore, they were not even aware of their duties and responsibilities, working hours; leave schedule and off days. This was majorly done verbally and this lead to the house helps to be overworked and underpaid. The house helps were not issued with a payslip at the end of the month and this made them not access loans from any financial institution, therefore, cannot be empowered.

The study showed that $70 \%$ of the house helps were discriminated on the following areas; food where in some houses the house helps were supposed to eat different menu from the other members of the family while some were not even allowed to take tea with milk and also to take meat, especially chicken. In $60 \%$ of some houses sampled the house helps were supposed to eat leftovers and also had specific plates and cups to eat from and had a specific amount to eat. In $50 \%$ of the houses, the house helps were supposed to eat from the kitchen while others ate from the dining area. In regard to social media, in $37 \%$ of the houses, the house helps were not supposed to make calls as the employer suspected that the house help might be looking for another place and the employers felt insecure. The study revealed that in $40 \%$ of the houses, the house helps were not allowed to watch the television with the family members neither to listen to the radio especially if she/he channelled the vernacular language.

Parties and outings; the study showed that in all the houses, the house helps were not allowed to hold birthday parties in their employers' house neither were they bought presents during their birthdays while the other family members were allowed to hold parties and bought presents. The study also showed that $90 \%$ of the house helps were also left out during the family outings unless the house help was to accompany them incise there was a responsibility to be carried out by her, e.g. swinging 
the children while the parents relaxed. In $79 \%$ of the houses, the house helps were not allowed to go outside the house either to talk to their neighbours. Medical care; the study showed that $90 \%$ of the house helps were not catered for when sick and were supposed to use their own resources when sick or were bought for pain killers when sick and were also expected to work when sick. In case a house help was discovered to be pregnant by the employer would suck her immediately with no notice neither a maternity leave was allowed.

Visitors; the study showed that $99 \%$ of the house helps were not allowed to bring visitors in the houses even in cases the employer was familiar with the visitors as some employers felt insure and some were suspicious of the visitors' intention. Training and induction; $90 \%$ of the house helps were not inducted to their duties and this affected their work performance since some of them had problems using electronic gadgets and gas. Workload; $40 \%$ of the house helps did not like working in homes with large families, especially families with small children or teenagers as they were overworked. The study also showed $10 \%$ of the house helps claimed that some employers forced them to dress in a certain way especially when the employer was from a different religion or belief. In $30 \%$ of the houses, the house helps were forced to follow the religion of the employer. Physical and sexual abuse; $40 \%$ of the respondents confessed to having been abused physically by the employer especially those below 20 years while $20 \%$ confessed to have been abused sexually by the employer either willingly or unwillingly and this was especially so if the employer was a male or in cases of domestic conflicts in the house.

Based on the findings, it shows that there are many factors that lead to a high turnover of the house helps in Shaabab estate, Nakuru town and the main factors were lack of job security, poor pay, overworking, lack of job induction, discrimination, and physical abuse. The study revealed that $30 \%$ of the employers advocated for better pay and 10\% suggested rewarding the house helps apart from paying them salaries. While 25\% advocated for work plan to avoid overworking the house helps while $35 \%$ suggested creating a good relationship with the house help and making them feel part of the family.

\section{CONCLUSION AND RECOMMENDATIONS}

The findings showed that the following factors lead to a high turnover of the house helps lack of terms and conditions of employment; poor pay discrimination, lack of training, overworking, domestic conflicts, religion, and dress code, sexual harassment and family size. The recommendations were that the employers of the house help should improve terms and conditions and provide a conducive work environment for the house helps. The house helps should also be educated on how to tackle some of these factors like sexual harassment. Some respondents were not well conversant with the English language and the research used Kiswahili. A case study design was adopted owing to the ability to provide information on population perception, attitude, option, views and behaviour about a given subject under study.

Based on this study, the following recommendations were made; The employers should provide a contract letter to the house helps to guarantee job security for a period of time where the terms and conditions should be well described to avoid overworking the house helps and also to ensure the recommended government domestic worker pay is adhered to avoid underpaying the house helps. The employers should also induct the house helps once employed especially on usage of some equipment and on some first aid skills which can be done internally or externally by involving an expert in order to improve their skills leading to a good performance of their duties. To ensure that the house helps are not physically or sexually abused by the employer, the house helps should be made aware of reporting such cases to the relevant authority for example to the chief, police station or to their guardians.

The researcher suggested that further studies to be conducted to find out the whether the law enacted by the government on domestic workers on matters pertaining salaries and national social security fund (NSSF) compulsory contribution is being adhered to manage some of these factors leading to a high turnover of the house helps. Also, further study should be done to find the mechanisms that can be put in place to ensure that house helps are issued with recognisable payslips by the banks in order to empower them through loan accessibility and also 
by the government especially with the introduction of the compulsory contribution of national social security fund (NSSF) by the government on all domestic workers which will enable the following their benefits claims in case of discrepancies. This will enable a good social-economic environment for the house helps to develop and achieve vision 2030.

\section{REFERENCES}

Armstrong. M. (2004). Human Resource Management, $10^{\text {th }}$ edition. London: Pitman publishers.

Boxall, P., Macky, K., \& Rasmussen, E. (2003). Labour turnover and retention in New Zealand: The causes and consequences of leaving and staying with employers. Asia Pacific Journal of Human Resources, 41(2), 196-214.

Clifton, A. (2000). A hard book of human resource Management $\left(6^{\text {th }}\right.$ Edition). New York: Palgrave publishers:

Cole, G. A. (2004). Personnel management theory and practices ( $6^{\text {th }}$ Edition). London: T. J International.

Gomez, C. S. (1994). Managing human resource. New Jersey: Prentice hall publishers.

Gupta, C. B. (2005). Human Resource Management. $6^{\text {th }}$ Edition. New Delhi: Sultan Chand and Sons Publishers.

Mobley, W. H., Griffeth, R. W., Hand, H. H., \& Meglino, B. M. (1979). Review and conceptual analysis of the employee turnover process. Psychological Bulletin, 86(3), 493.

Muasya, G. (2014). The role of house helps in work-family balance of women employed in the formal sector in Kenya. In Work-family interface in sub-Saharan Africa (pp. 149-159). Springer, Cham.

Mullins, L. (2002). Management and organisational behaviour. $6^{\text {th }}$ Edition. London: Pitman Publishers.

Nyaura, J. E., \& Ngugi, M. N. (2019). The plight of the house-helps (domestic workers) in selected estates in Eastland area, Nairobi county, Kenya. People: International Journal of Social Sciences, 5(2). 